\title{
Geophysical study of a crustal section across the Straits of Messina (")
}

\author{
A. Botrari $(* *)-$ E. Lo Giudice $(* * *)-D$. Schiavone $(* * * *)$
}

Received on October 18th, 1979

\section{ABSTRACT}

This paper presents the results of geophysical researches which can contribute to a better definition of a structural model for the Straits of Messina. It is part of the seismological researches, particularly of seismic microzonation, which are being carried out in the area of the Straits.

The crustal model proposed for a cross section of the Straits has been based, for its upper part, on data of dipole electrical soundings and, for its deeper structures, on seismological observations and on their comparison with data of active seismic.

the Graben structure of the Straits recently proposed, with the Calabrian The obtained section emphasize, with some detail in the upper part,

(*) This work has been performed with the financial aid from the National Research Council (Italian Geodvnamical Project, publication n. 239). (Italy).

(*:*) Istituto Geofisico e Geodetico, Università di Messina, Messina

$(* *)$ Istituto Internazionale di Vulcanologia, C.N.R., Catania (Italy).

(****) Istituto di Geodesia e Geofisica, Università di Bari, Bari (Italy). 
block structurally in a higher position than the Sicilian one. Such structural character has been put in evidence by refraction seismic sections to a depth of about $18 \mathrm{Km}$.

The correlation between the structures of the area surrounding the Straits and the hypocentral distribution for the heaviest earthquakes with focus in the area is pointed out.

\section{RIASSUNTO}

In questo lavoro sono presentati i risultati di indagini di tipo geofisico come contributi per una migliore definizione di un modello strutturale per lo Stretto di Messina. In una visuale più ampia ciò rientra nel contesto degli studi sismologici ed in particolare di indagini di microzonazione sismica in atto nell'area dello Stretto.

Più precisamente è proposto un modello crostale lungo una sezione dello Stretto ricavato, per la parte superiore, utilizzando dati di prospezione elettrica dipolare, ed a livello di strutture profonde, tramite osservazioni sismologiche ed il loro confronto con dati di sismica attiva.

La sezione presentata è caratterizzata, con un buon dettaglio nella parte superficiale, da una struttura a graben, con il blocco calabrese più sollevato rispetto a quello siciliano. Tale circostanza è riscontrabile, in base alle sezioni da sismica a rifrazione, sino alla profondità di circa $18 \mathrm{Km}$.

E' poi messa in evidenza la correlazione esistente tra le strutture delineanti l'area dello Stretto e la distribuzione degli ipocentri per i maggiori terremoti originatisi nell'area.

\section{INTRODUCTION}

Seismic microzonation generally means the study of the influence of the local site conditions on the surface motion produced by earthquakes. Some observed effects, however, cannot be satisfactorily explained unless other data are considered, which concern geologic and topographic features of a wider area than the site of interest.

This is particularly true for geologically complex areas such as the one of the Straits of Messina.

So far as seismic microzonation researches in this area are concerned, the first and most important problem to work out 
has been to attempt a better knowledge of deeper structures and rock units.

For this purpose we have performed, in the study of the upper part of the chosen profile, geoelectrical investigations, deeming such methodology well discriminates the geologic formations of the area.

For the characterization of the crustal extent of the structures obtained through geoelectrical and geological interpretations, we have used seismological methodologies comparing then the results with active seismic data.

In an area of so great a seismogenetic interest, which, however, is not yet sufficiently known, the above suggested approach can be useful from many points of view.

\section{GEOLOGICAL AND STRUCTURAL FEATURES}

The Straits of Messina are the most important tectonic discontinuity cutting across the southern part of the CalabroPeloritan Arc (fig. 1). This arc, which was formed during the Apenninic orogenesis, stretches from Capo d'Orlando in Sicily, through the Peloritan mountains, the Aspromonte, the Serre and the Sila, to the plain of Sibari in Calabria, bending towards the Thyrrenian sea. The Arc is mainly constituted by a complex consisting of plutonic rocks, of ercinic metamorphites and of mesozoic and tertiary sedimentary rocks.

The complex, known as "Calabride", consists of different overthrust units, SE vergent, which were emplaced between the Mesozoic and the Miocene.

Many hypothesis have been suggested about the structure of the Straits. Recent studies of neotectonics and marine geology (Ortolani, 1975; Ghisetti and Vezzani, 1978; Selli, 1978; Barbano et al., 1979) support the assumption of a graben structure. After the orogenic phase, a transgression took place in the Tortonian, with the deposition of conglomerates and sandstones of lagoonshore environment. In this period a first postorogenic tectonic phase took place with the formation of some subsiding basins 
(Caltanisetta, the Mesima river, Catanzaro and Sibari). In these basins the sedimentation evolved to evaporitic deposits.

Between the Lower and Middle Pliocene a compressive tectonic phase took place causing the persistent southeastward shifting of the Arc. Then the folding of the sedimentary series of the above mentioned basins occurred with the consequent formation of the synclines of Messina, Pace del Mela and Mélito di P.S. The beginning of the breaking of the Arc into blocks can be attributed to this period, together with transcurrent movements along the Tindari-Giardini line.

The following tensional tectonic phase, between the Upper Pliocene and the Preglacial Pleistocene, more directly concerns the genesis of the Straits. The internal part of the Arc was affected by vertical movements, with the formation of monoclinal, longitudinal grabens and horsts. Consequently gravitative slides took place outside. The graben of the Straits of Messina, produced by the main tension WNW-ESE, is bounded by the faults of Portella Arena and Gallico. The block of the Piani di Matiniti, SSW limited by the fault of Petrulla, is uplifted on the Calabrian side. The breaking of the Arc into transversal and longitudinal blocks, which occurred in this period, was furtherly emphasized during the subsequent tectonic phase. The longitudinal faulting gave an antiform structure with graben in the bend.

Between the blocks of Sibari and Catanzaro, the Sila one, in the northern part of the Arc, is divided in two longitudinal NNW-SSE blocks by the graben of Crati. The graben of Catanzaro act as a bend of the mountain range where the trend its main axis show a significative variation. Southern Calabria, bounded by the graben of Messina to the south, is longitudinally divided by the graben of the Mesima trending NE.

A further transversal breaking (the graben of Siderno), separating the Serre from the Aspromonte, becomes more evident in the subsequent tectonic phase.

This last phase developed from the Upper Pliocene on, and consisted of tensional movements, which brought about normal faults and great uplifts, with the formation of various series of 
terraces. The Calabrian side of the Straits underwent a greater uplift. As far as the oldest terrace (Glacial Pleistocene) is concerned, a difference of about $318 \mathrm{~m}$ can be observed between the sides of he Straits (Selli, 1978).

According to Selli (1978), the complete clearing of the sides of the Straits was due to this phase; with the opening of the graben constituting the northern access, the Straits assumed their present shape.

This phase, which produced faults and lineaments (in the saddle of the Straits) E-W, N-S, NW-SE and reactivated preexistent faults, is probably characterized by a main tension NW-SE and a slight tension NE-SW, which determined a conjugated system E-W, N-S.

SEISMIC MODEL OF THE CRUSTAL SECTION

In the previous section were presented the geological and structural characteristics of the Straits of Messina and of their genesis at a crustal level.

No direct elements are available through which it is possible to obtain the vertical extent, in the whole thickness of the crust, of the discontinuities concerning the Straits, and a crustal model for the same area.

Besides, the analysis of the crustal sections obtained through deep refraction seismic in neighbouring areas - Aeolian Islands, Mounts Nebrodi, eastern side of Etna, Lower Ionian, and Southern Calabria - point out a eleat complexity in the area of the Straits, in spite of its extension.

The crustal sections shown in fig. 2 refers to the points marked on the seismic profiles in fig. 1; as far as the intersection points between two profiles are concerned, the sections presented are the results of averages and the synthesis of known data.

$A$ and $G$ sections refer to a "thinned " continental crust (Cassinis et al., in print), showing a total thickness not exceeding $20 \mathrm{Km}$ and a character which can be compared with the "subcontinental " crust, as defined by Kosminskaya and Zverev 
(Drake \& Kosminskaya, 1968). Further evidences on the continental nature of the crust in that area have been contributed by geological data pointing out the frequent occurrence of

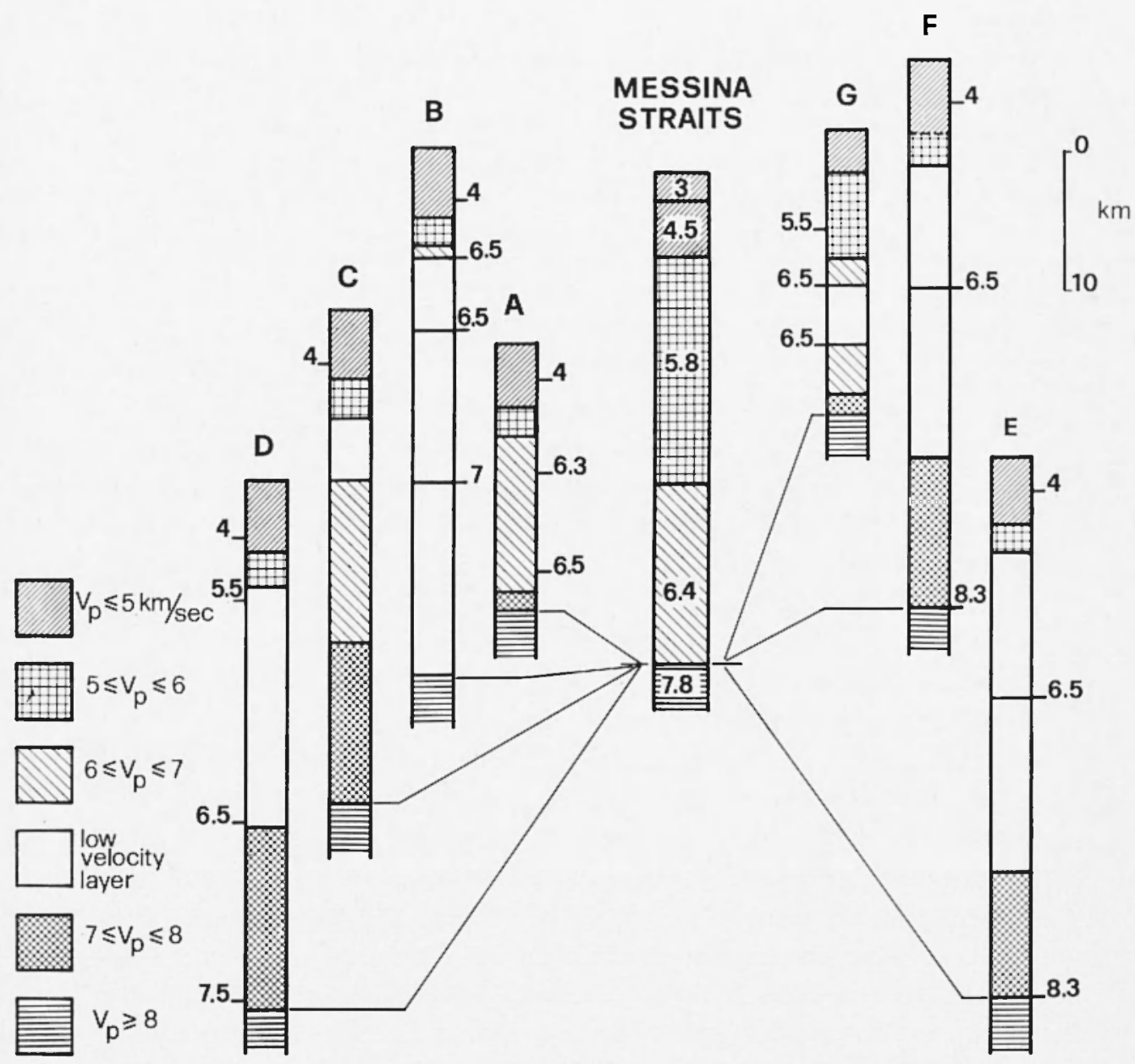

Fig. 2 - Comparison between the crustal section for the Straits obtained through seismological observations and the sections from deep seismic surveys taken in the points marked in fig. 1. The numbers on the sections represent values of velocity. 
metamorphic xenolithes in the volcanic products from Aeolian Islands (Honnorez \& Keller, 1968). A thicker "sub-continental » crust is observed in section $\mathrm{B}$, showing the occurrence of lowvelocity layers. The other sections reported in fig. 2 refer to a $30-$ $40 \mathrm{Km}$ thick crust, to be regarded as a "normal continental tvpe » (Giese \& Morelli, 1975; Cassinis et al., 1979). Typical characters to be emphasized are the presence of poorly developed lowvelocity layers and the occurence of a well developed underlying "transitional zone " $\left(7-8 \mathrm{Km} \cdot \mathrm{sec}^{-1}\right.$; Cassinis et al., in print). The P-wave velocity in the upper mantle appear to be "normal " $\left(\mathrm{V}>8 \mathrm{Km} \cdot \mathrm{sec}^{-1}\right)$.

A contribution to a better definition of a crustal model for the area of the Straits comes from the study of the propagation of the elastic waves. The data, collected by the local network since November 1977, make it possible a first quantitative approach to the solution of the problem (Bottari et al., 1979).

The useful data comes mainly (more than 300 analysed data) from the seismic crisis which developed in the gulf of Patti in the Spring of 1978 (Barbano et al., 1979) and in smaller amount, though of great reliability, from the explosions in the Ionian of the November 1977 (fig. 1), which were gathered on behalf of the Department of Geodesy and Geophysics of Cambridge University, U.K. (Sharpe et al., 1978).

The analysis of the observations of the seismic activity in the gulf of Patti, together with the preliminary assumption of a flat, parallel crustal layering, has made it possible to obtain the velocity of longitudinal waves along some refractors.

All data refers to the range of distances $0.1 \leqslant \Delta^{\circ} \leqslant 2.0$, with a greater density nearly in the range $0.2 \leqslant \Delta^{\circ} \leqslant 1$. The errors in the arrival times of the phases - generally first arrivalsare negligible, both for the instrumental characteristics of the stations and for the nature of the onset of the events, which shown prevalently as an "impetus".

For the seismic events considered (of magnitude $\geqslant 3.0$ ) it is known the preliminary hypocentral determination carried out by I.N.G. (National Institute of Geophysics) using a twolayers crustal model. In the following we will denote this model 
by MAA; it is characterized by the following values of thickness and velocity:

$$
\begin{array}{ll}
\mathrm{h}_{1}=25 \mathrm{Km} \quad ; \quad \mathrm{v}_{1}=5.3 \mathrm{Km} / \mathrm{sec} . \\
\mathrm{h}_{2}=27 \mathrm{Km} \quad ; \quad \mathrm{v}_{2}=6.6 \mathrm{Km} / \mathrm{sec} .
\end{array}
$$

Two groups of traveltimes have been analysed so that a crustal model for the area of interest might be elaborated. In MAA model the groups correspond to two classes of focal dephts, of $10+5 \mathrm{Km}$ and of $20+5 \mathrm{Km}$ respectively.

Four phases of refracted longitudinal waves have been observed on the whole. They are characterized by the following equations:

$$
\begin{aligned}
& \mathrm{T}_{1}=(1.26+0.30)+(19.03 \pm 0.54) \\
& \mathrm{T}_{2}=(3.86 \pm 1.02)+(17.14+0.58) \\
& \mathrm{T}_{3}=(2.51 \pm 0.11)+(17.34 \pm 0.21) \\
& \mathrm{T}_{4}=(5.97 \pm 0.29)+(14.23 \pm 0.27)
\end{aligned}
$$

The crustal model elaborated through a feed-back process with the observed data (MSM model) is characterized by four layers (Bottari et al., 1979). The first two layers, which cannot be put in evidence through the available seismological data, are presented with values of thickness and velocity on the base of a synthesis of active seismic data (Cassinis et al., 1969; Morelli, 1970; Scarascia and Colombi, 1971; Giese and Morelli, 1975; Morelli et al., 1975). The third layer, comparatively the thicker one and the most active during the crisis in the gulf of Patti, agrees with the difference of the intercept times on the time- 
distance curves of equations [1] and [2], for values of thickness and velocity of $16 \mathrm{Km}$ and $5.8 \mathrm{Km} / \mathrm{sec}$ respectively. In the same way it is confirmed for equations [3] and [4] the correspondence to the deepest layer, for a thickness of $13.5 \mathrm{Km}$ and a velocity of $6.4 \mathrm{Km} / \mathrm{sec}$.

The results of the seismological work are presented in the section of the Straits in fig. 2. The velocity in the lower crust appears comparatively low, also in respect to refraction seismic interpretations in the area of the Nebrodi and the Peloritan mountains (sections $\mathrm{B}, \mathrm{C}$ and $\mathrm{D}$ in fig. 1 and fig. 2). That may show the presence of low velocity layers.

The reliability of the suggested crustal model has been tested on the base of the traveltimes of the three explosions in the Ionian (fig. 1). If we consider the difference in the travel of the seismic waves and consequently the different characteristics of the media interested by the seismic energy, the observations presented can be of some interest. For the Ionian side of the Straits, the few data available show a crust considerably different from MSM model, particularly in the intermediate layers. The correspondence is satisfactorily, however, so far as the values of velocity of $P_{n}$ and the thickness of the crust are concerned.

\section{DIPOLE ELECTRICAL SOUNDINGS}

In the area under consideration two vertical electrical soundings have been performed, by dipole tecnique. These soundings, together with the stratigraphic boreholes of Cannitello and Ganzirri (fig. 8), allowed a geological section to be suggested.

Such technique has been chosen because of its remarkable advantages, from the practical point of view, in respect to the classical Schlumberger or Wenner arrays, particularly for the possibility of obtaining high depths of investigation.

The axial arrangement has been used for this research (fig. 3); the emitting dipole $\mathrm{AB}$, shift on a line according to the receiving one $\mathrm{MN}$, so that a greater simplicity both on the practical and on the interpretative level is attained. 
The measuring technique consists in:

a) energinzing the ground by repead square current wave forms with a period of 10 seconds and for a time between 10 and 30 minutes;

b) sampling the voltage signal at intervals of two seconds;

c) extracting the useful signal, masked by the telluric noise, through spectral analysis (Loddo and Patella, 1977).

For a detailed description of the method and further examples of applications to structural problems see recent studies (Nardi et al., 1979; Patella et al., 1979).

The above mentioned technique has made it possible to obtain the diagrams of apparent dipole resistivity versus spacing shown in fig. 4 and fig. 5.

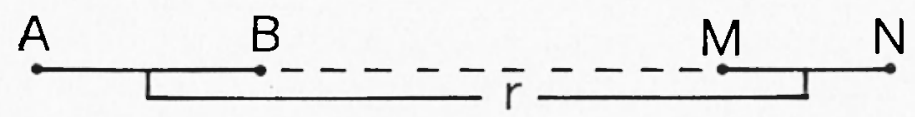

Fig. 3 - Depiction of the dipole configuration used. $r$ is the spacing.

For the quantitative interpretation of the dipole diagrams, they have been transformed into Schlumberger diagrams ( $\mathrm{Pa}$ tella, 1974), so that it has been possible to adopt all the interpretative techniques already developed for Schlumberger soundings and, moreover, to smoothe away the curves, thus suppressing the local anomalies generally present in dipole soundings and underlining all the contrasts of resistivity with structural character.

Fig. 6 shows the transformed diagram for the sounding DES 1. Remarkable lateral effects can be observed, which make it different from the typical behaviour of horizontal layers situations. Also in this case an interpretation can be obtained on the base of the hypothesis of horizontal lavers and then taking into consideration the lateral discontinuities (Patella, 1977; Patella et al., 1979). 


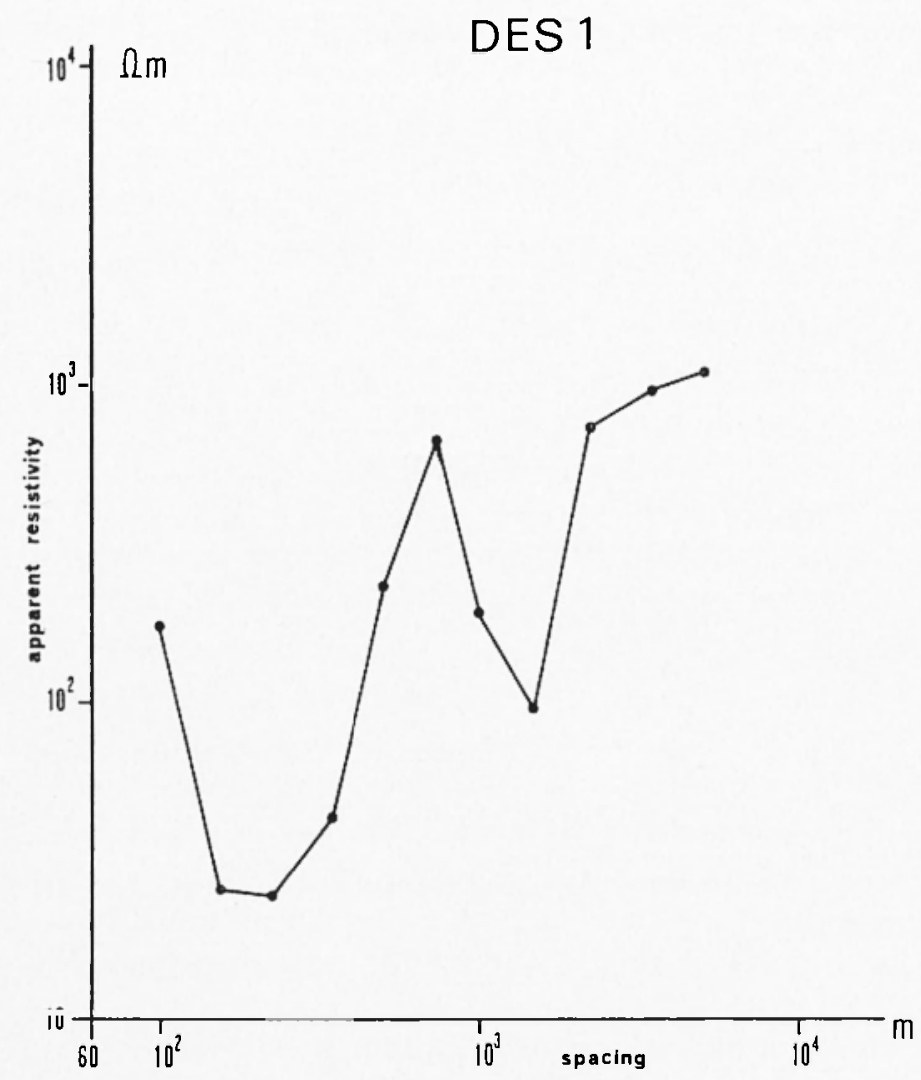

Fig. 4 - Dipole apparent resistivity diagram for DES 1.

The horizontal layers model suggested (full line curve on the figure) is characterized as follows:

$\begin{array}{lll}\text { Layer } & \text { Resistivity } & \text { Thickness } \\ \mathrm{I}^{\circ} & \varrho_{1}=90 \Omega \mathrm{m} & \mathrm{t}_{1}=\mathrm{I} 40 \mathrm{~m} \\ \mathrm{II}^{\circ} & \varrho_{2}=650 \Omega \mathrm{m} & \mathrm{t}_{2}=200 \mathrm{~m} \\ \mathrm{III}^{\circ} & \varrho_{3}=3100 \Omega \mathrm{m} & \end{array}$

For the geological correlation of the three electrostrata, the first low resistivity layer can be associated to saturated sands 


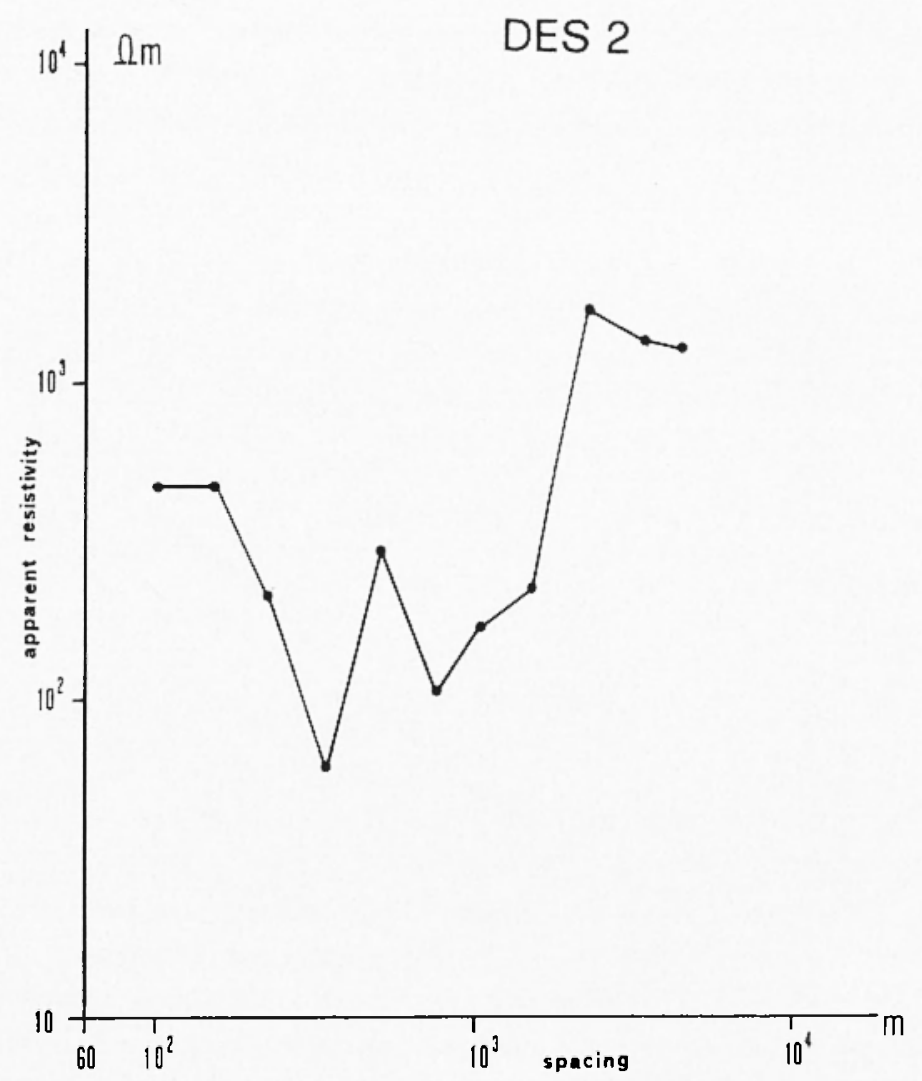

Fig. 5 - Dipole apparent resistivity diagram for DES 2.

and gravels belonging to the outcropping "Formazione di Messina" and the underlying Tortonian sediments. That is confirmed by geological surface data and by stratigraphic boreholes. Then there is a comparatively thick formation which can be attributed to altered metamorphic rocks; all that lies on the compact metamorphic basement.

The lateral effects can be interpreted, from the qualitative point of view, through a comparison with the set of master curves published on Al'pin (1966).

The diagram shows three peaks that can be associated to the transit of the moving current dipole across vertical contacts. 
On the base of the spacing to which such contacts can be referred and of geological-structural data, the first lateral effect may be caused by the presence of a shallow lens of sedimen-

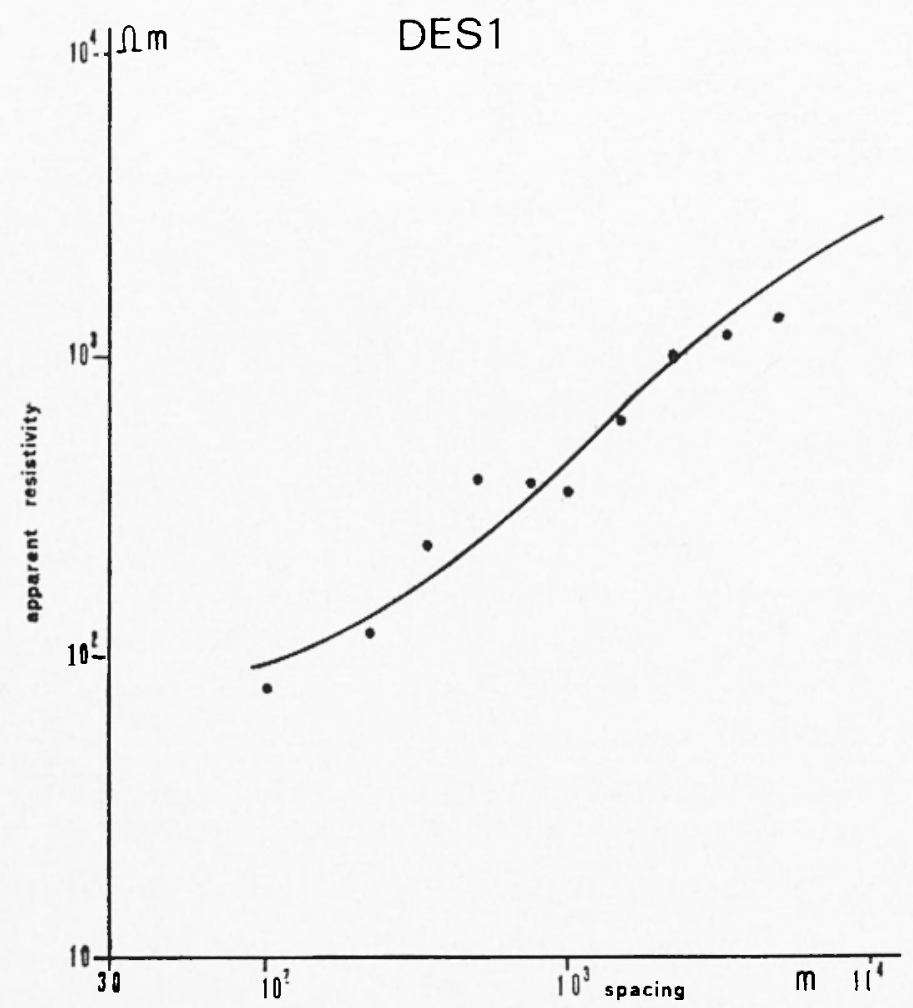

Fig. 6 - Dipole to Schlumberger transformed diagram for DES 1.

tary formations with a resistivity higher than the "Formazione di Messina", as for example the Middle Pliocene sediments outcropping slightly to the west of the centre of the sounding. The other two lateral effects, which can be observed at a greater spacing, may be referred to a lowering, in correspondence to the two faults crossing the profile (fig. 8), of the high resistivity metamorphic basement. 
Further information can be obtained about the basement assuming the presence of a further layer below it with extreme values of resistivity $\rho=0, \rho=\infty$ (Alfano, 1974). The interpretation of the two limit situations makes it possible to attribute to the basement a minimum thickness of $2 \mathrm{Km}$.

Fig. 7 shows the transformed diagram of the sounding DES 2. Though it shows a more regular behaviour than the previous one, it appears to be equally influenced by a lateral effect. The experimental points are fitted with a three layers curve corresponding to the following values of the parameters:

$\begin{array}{lll}\text { Layer } & \text { Resistivity } & \text { Thickness } \\ I^{\circ} & \rho_{1}=105 \Omega \mathrm{m} & \mathrm{t}_{1}=60 \mathrm{~m} \\ \mathrm{II}^{\circ} & \rho_{2}=550 \Omega \mathrm{m} & \mathrm{t}_{2}=180 \mathrm{~m} \\ \text { III }^{\circ} & \rho_{3}=2800 \Omega \mathrm{m} & \end{array}$

The geological interpretation of the electrostratigraphy is based not only on surface geology and on the stratigraphy of boreholes, but also on several unpublished data from drillings and shallow electrical soundings. So it is possible to correlate the first layer to superficial coarse alluvia and to the Middle Pliocene formation locally moved downward by a fault. The second low resistivity layer can be related to an altered metamorphic basement.

The lateral effect can be attributed to a rising of the basement, along the line of development of the sounding, which can be observed about $1500 \mathrm{~m}$ far from the centre. Considering that the sounding has been performed along the right shore of the Fiumara of Catona, the rising of the basement might be constituted by a small structural salient, like the one of the Piani di Matiniti, but not outcropping.

For the thickness of the basement, a minimum value of 1.5 $\mathrm{Km}$ is obtained by the method described above.

A comparison between the two electrical soundings shows a difference in the values of resistivity obtained for the altered granite. That is confirmed by the electrical data on the outcrop- 


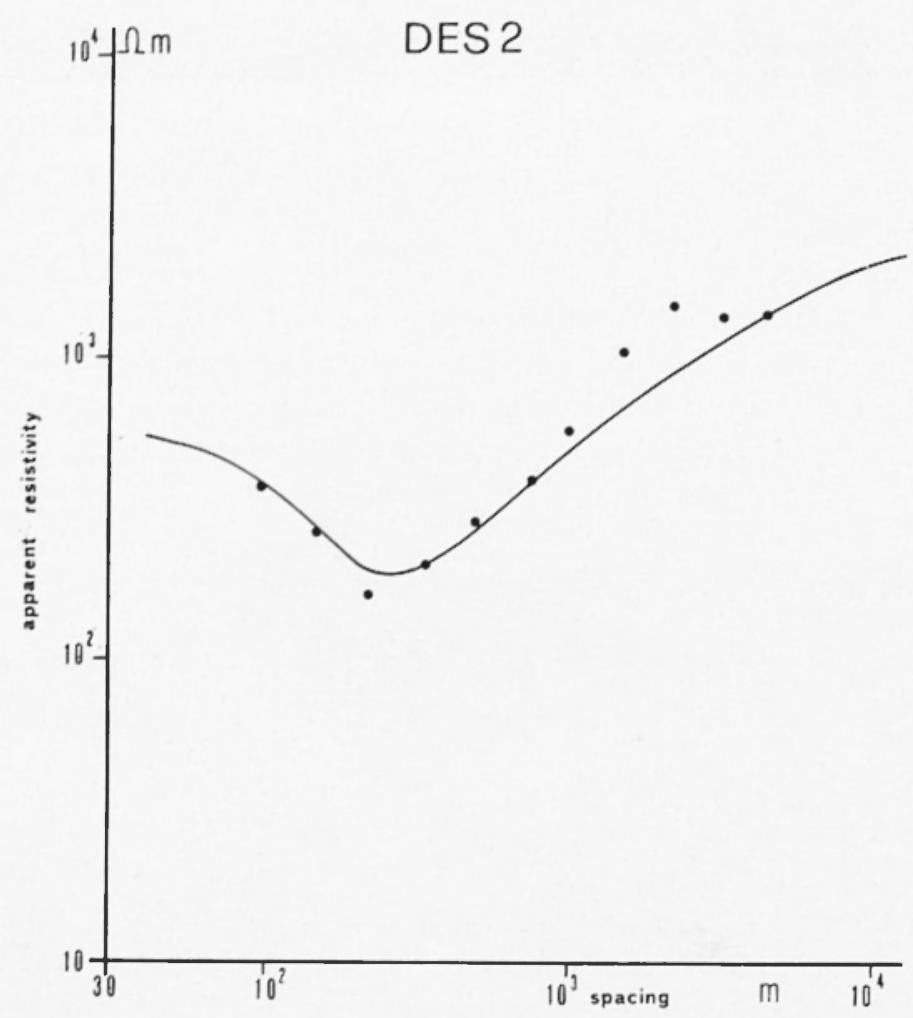

Fig. 7 - Dipole to Schlumberger transformed diagram for DES 2.

ping of the basement obtained on both sides by Cassinis (1963) and by unpublished data.

In the sounding DES 2 the comparatively low resistivity attributed to altered granite might be caused by fluids permeating a shallow fault system. So far as it is known on the base of available information, there is, in any case, a different alteration for the metamorphic rocks on both sides, which is well known from the geological point of view.

Fig. 8 presents a model of the structures along the profile, resulting from the correlation between the interpretations of the electrical data and of the stratigraphic boreholes together with surface geological data. 


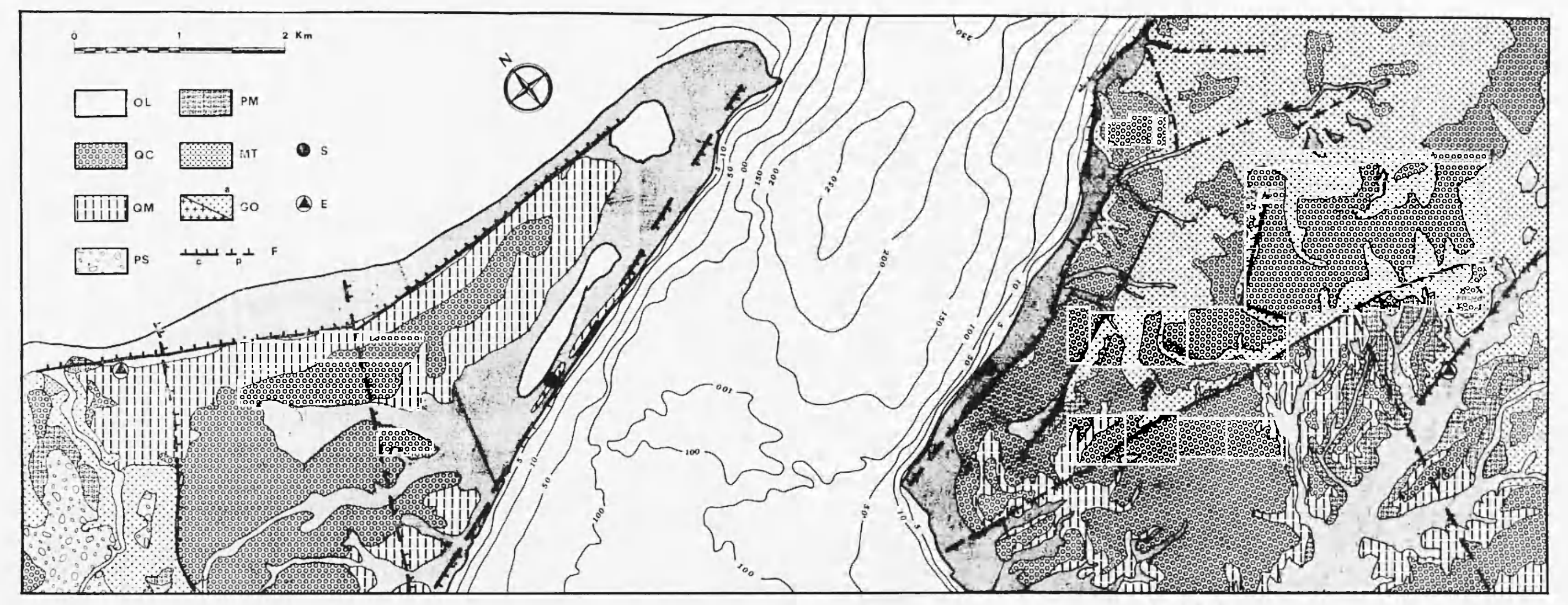

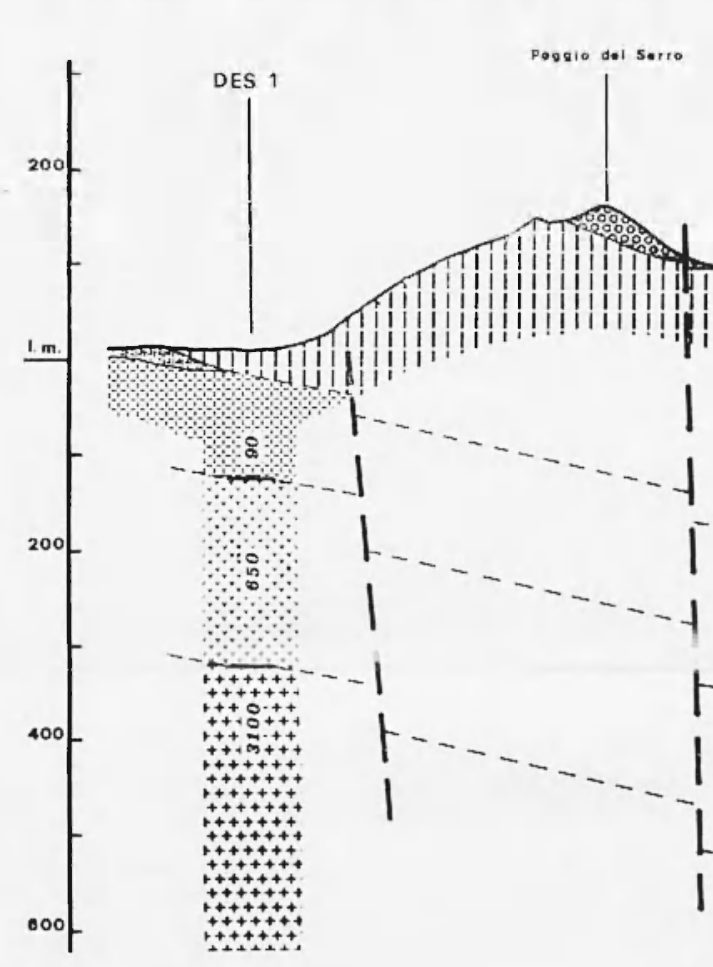

Fig. 8 - The geological map shown in the figures has been obtained through a synthesis of data of Malatesta and Motta (1961) for Sicily, and of Hughes (geologic map of Calabria, 1968) to the Calabrian side. The profile has been obtained through a match of the results of the electrical soundings of Contrada Ortara (Sicily) and of San Nicola (Calabria) with surface geological data and the ones coming from the sratigraphic boreholes performed by Agip (Selli, 1978).

OL - Olocene: recent littoral deposits, sandy and pebbly alluvial deposits; eluvial deposits, alluvial fan, some times with calcareous cement, alluvial cones. Highly permeable materials with thickness of some tens of meters.

$\mathrm{OC}$ - Continental Pleistocene: conglomerates and ar cosic sands, brown-reddish, sometimes terraced. Loosely consolidated with high permeability. The thickness is over $100 \mathrm{~m}$ at the lower levels and about $20 \mathrm{~m}$ in the higher terraces.

$O M$ - Marine Pleistocene: sandy-conglomeratic deposits with small and big pebbles, grey-brown, sometimes yellowreddish with Ostrea-Cardium (Sicily) and Mya Truncata (Calabria). Loosely consolidated with high permeability. The maximum thickness is about $300 \mathrm{~m}$. Near the base they are substituted by vlinostratified deposits ("Formazione di Messina ") in deltaic facies, and by organogenous

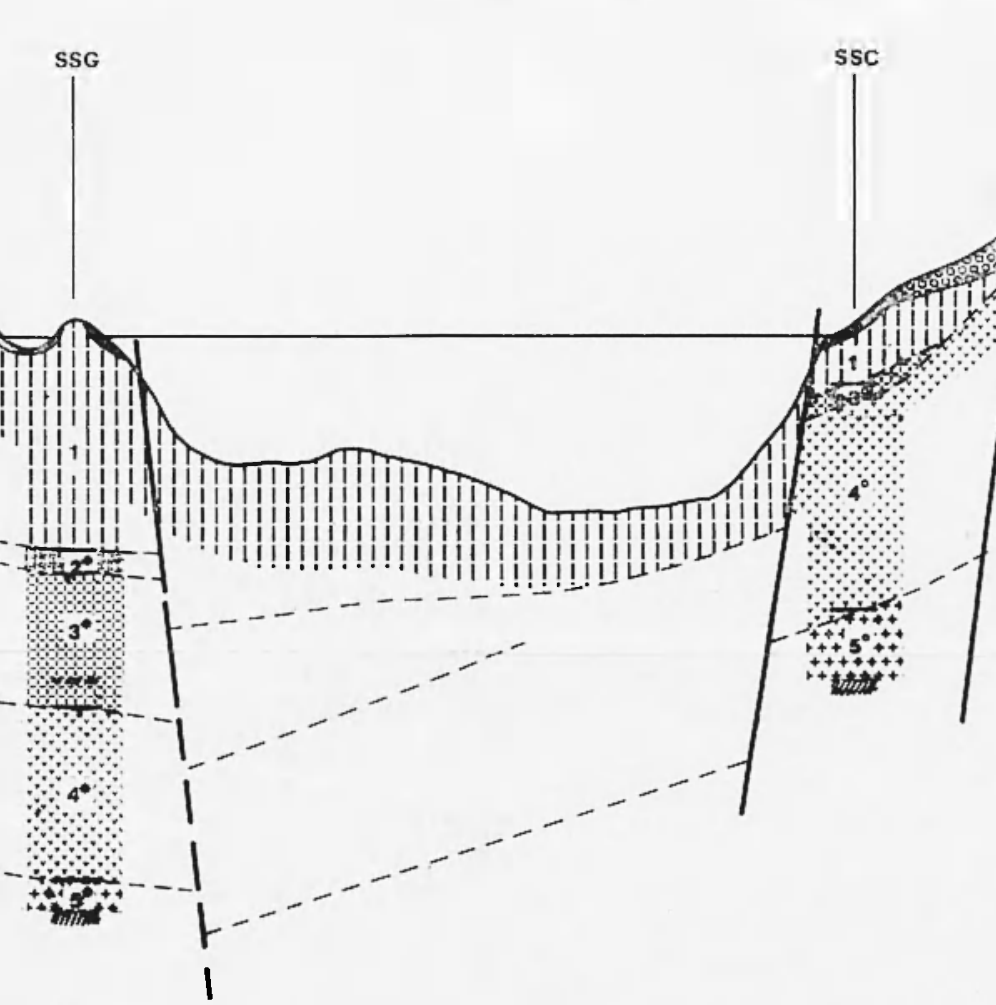

limestones and by conglomerates and arcosic sands, greybrown, with lenses of fossiliferous sandy clay of shore facies. This transgressive formation outcrops on the high sea floors of the Straits, where the limy types are still in formation.

PS - Middle-Upper Pliocene: fine or middle grained sands, variously cemented, with crossed stratification, with calcarenitic sandy-arenaceous intercalations and conglomeratic fossiliferous intercalations (Aequipecten scabrellus, ostrea cohlear, etc.). Compacted deposits and resistant to erosion. High permeability with observable thickness about $50 \mathrm{~m}$.

PM - Lower-Middle Pliocene: clays and whitish marls ("Trubi") with bentonic and planctonic foraminifera and fine-grained silty sands, locally clayey, sometimes with intercalations of sands and calcarenites; heteropic and/or basal conglomerates are also present. This complex is easily erodible, scarcely permeable and 30 to $100 \mathrm{~m}$ thick.

$M T$ - Tortonian: thick beds of conglomerates with intercalation of sands and micaceous sandstones and, sometimes, clayey lignitiferous lenses of lagoon shore environment. This formation, transgressive on metamorphic units, outcrops prevalently on the Sicilian side. In the area under consideration it is present in small north-western outcrops.

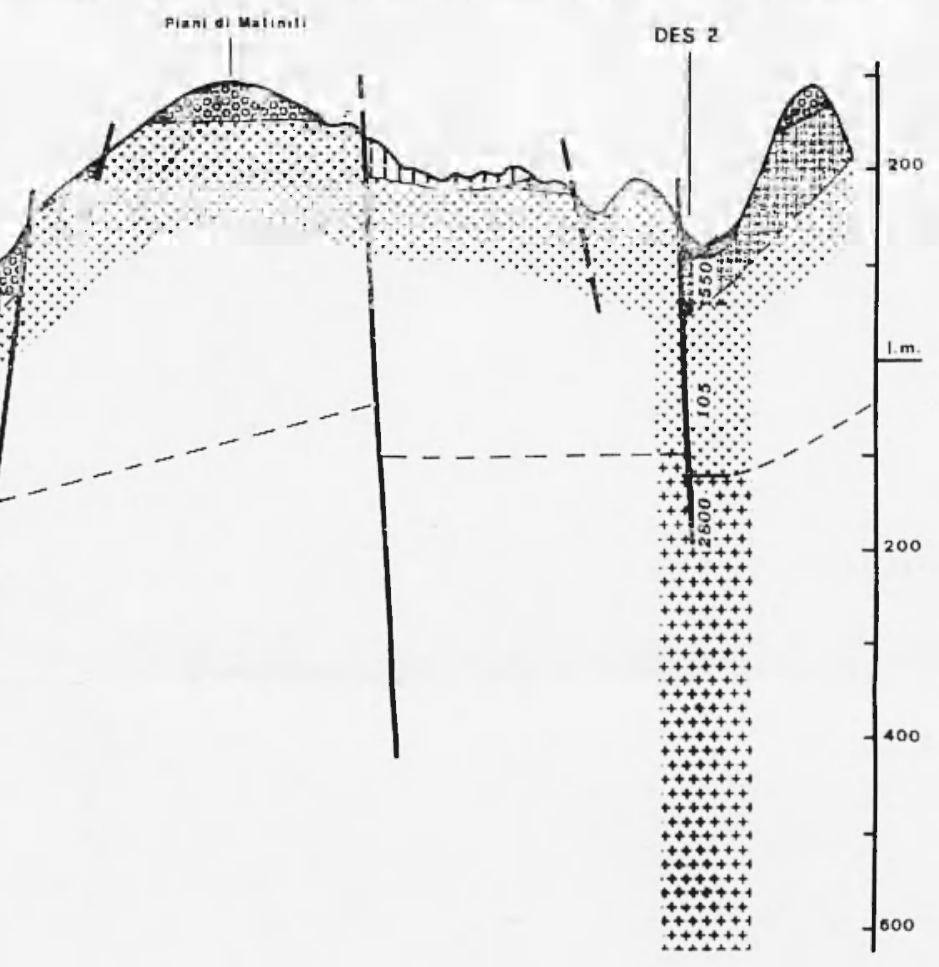

GO - Igneous and Metamorphic rocks: granites, augengneiss, biotitic schists, phyllites, pegmatites etc.; palaeozoic complex metamorphized in ercinic age. Owing to tectonic transport undergone in alpine age and to subaerial degra dation during the middle-upper Miocene, it is of ten highly cataclastic or arenitized (a).

F - Real (c) or Probable (p) Faults.

S - Stratigraphic boreholes of Ganzirri (SSG) and Cannitello (SSC).

E - Electrical soundings of Contrada Ortara (DES 1) and of San Nicola (DES 2).

1 - Gravels and sands of the "Formazione di Messina " (Marine Pleistocene).

2 - Clayey marls ("Trubi») of the Lower Pliocene.

3 - Sands and gravels of the Messinian and Tortonian, overlying coarse sands of the Tortonian $\left(3^{*}\right)$; sands with intercalations of sands and pebbles of the Tortonian $\left(3^{\circ}\right)$.

4 - Degradation zone of the metamorphic basement: sharp-edged fragments and metamorphic and granitic pebbles (also volcanic) of the Tortonian (?), $\left(4^{\star}\right)$; cataclastic, arenitized granite $\left(4^{\circ}\right)$.

5 - Metamorphic rocks of the basement $\left(5^{\star}\right)$; augergneiss $\left(5^{\circ}\right)$. 


\section{CONCLUDING REMARKS}

The analysis of the model presented on the base of geological data and of geoelectrical observations confirm tre graben structure of the Straits and, in particular, underline the greater uplift of the Calabrian side, an outstanding element which can be clearly observed in spite of the local structures.

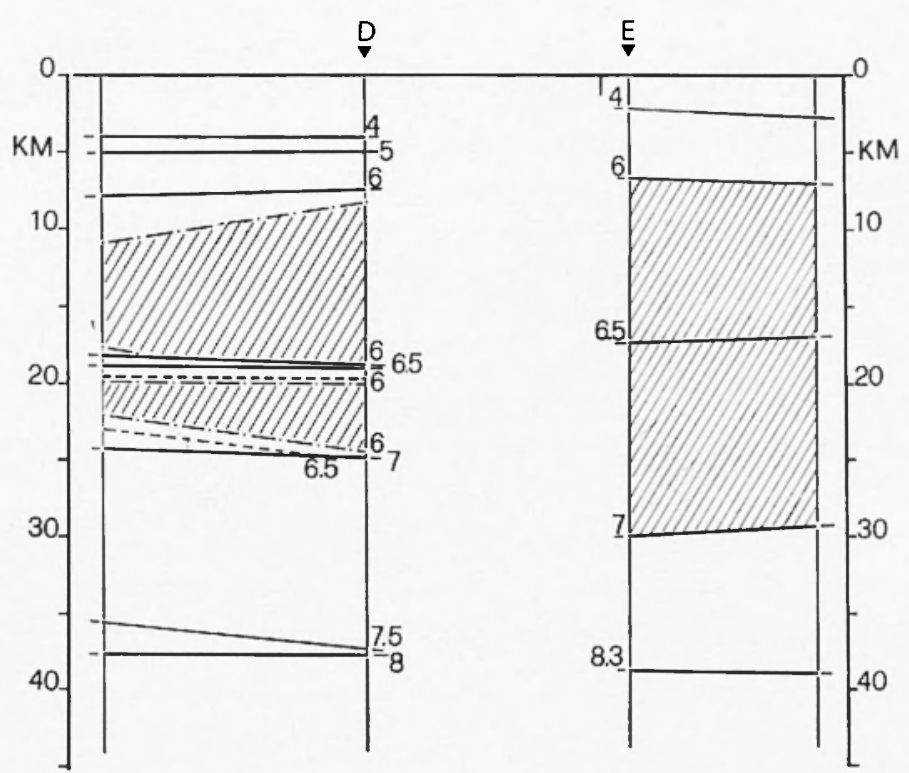

Fig. 9 - Crustal sections models corresponding to points D and $E$ of fig. 1, in the southern shores of the Straits.

On the other hand the suggested synthesis of the data of deep seismic soundings and of seismological observations, though it offers a crustal model for the area of the Straits which agrees with the behaviour of Bouger's isoanomalies (Cassano et al., 1978), does not allow to see whether and down to what crustal level the above mentioned crustal discontinuity extends. To this purpose the two crustal sections nearer to 
the shores of the Straits are examined (fig. 9). So far as the velocities of the longitudinal waves along the refractors are concerned, such crustal models agree, though the crust of the Sicilian side presents, in its upper part, a greater complexity. particularly interesting is the result of the analysis of the thicknesses of the layers in the two sections. It shows that the relative uplift of the Calabrian side can be observed down to about $18 \mathrm{Km}$.

It is a fact of particular interest that the foci of the heaviest earthquakes in the Straits, for which the focal depth has been determined analitically and/or macroseismically (Bottari and Lo Giudice, 1975) are situated between 12 and $20 \mathrm{Km}$.

Such correlation represents, in our opinion, the first and the most important result in the context of the acquisition of all those informations on which a seismic microzonation study must be based.

\section{ACKNOWLEDGEMENT}

The authors wish to thank Dr. D. Patella, Institute of Geodesy and Geophysics, University of Bari, for giving useful suggestions during the execution and interpretation of the dipole electrical soundings. 


\section{REFERENCES}

Alfano L., 1974 - A first application of electrical dipole-dipole soundings to the calcoreous formations in the central Apennines. "Riv. It. di Geof. ", 23, pp. 101-118.

AL' Pin L.M, Berdichevskit M.N., Vendritsev G.A., ZaGarmistr A.M., 1966 Dipole methods for measuring earth conductivity (translated from Russian by G.V. Keller). Consultants Bureau, New York.

Barbano M.S., Carozzo M.T., Carveni P., Cosentino M., Fonte G., Ghisetti F., Lanzafame G., Lombardo G., Patanè G., Riuscetti M., Tortorici L., Vezzani L., 1979 - Elementi per una carta sismotettonica della Sicilia $e$ della Calabria. "Presented at the 69th Meeting of the Societa Geologica Italiana, Perugia, $2-4$ oct. 1978 ".

Barbano M.S., Bottari A., Carveni P., Cosentino M., Federico B., Fonte G., Lo Giudice E., Lombardo G., Patanè G., 1979 - Macroseismic study of the Gulf of Patti earthquake in the geostructural frame of NorthEastern Sicily. In Press.

Bottari A., Lo Giudice E., 1975 - Studio macrosismico del terremoto di Reggio Calabria del 16 gennaio 1975. "Ann. Geofis. », 28, pp. 151-176.

Bottari A., Broccio F., Federico B., Lo Giudice E., 1979 - Preliminary crustal model from seismological observations at Messina Straits network. In Press.

Carta Geologica dello Stretto di Messina, 1961 - Regione Siciliana, Assessorato per i lavori pubblici.

Carta Geologica della Calabrin, 1968 - Cassa per il Mezzogiono.

Cassano E., Cavaciocchi D., Fiorilli G., Maino A., 1978 - Carta gravimetrica della Sicilia. Anomalie di Bouger. "Boll. Serv. Geol. d'Italia ", 99.

Cassinis R., 1963 - Piano di studi sullo Stretto di Messina per il collegamento della Sicilia con la Calabria. Stamperia C. Tamburini, Milano.

Cassinis R., Finetti I., Giese P., Morelli C., Steinmetz L., Vecchia O., 1969 - Deep seismic refraction research on Sicily. "Boll. Geof. Teor. Appl. », 11, pp. 140-160. 
Cassinis R., Franciosi R., Scarascia S., 1979 - The structure of the earth's crust in Italy. A preliminary typology based on seismic data. "Boll. Geof. Teor. Appl. ". In print.

Drake C.L., Kosmiskaya I.P., 1969 - The transition from continental to oceanic crust. "Tectonophysics ", 7, pp. 363-384.

Ginsetti F., Vezzani L., 1978 - Dati preliminari sulla Neotettonica dei Fogli 252 (Naso), 253 (Castroreale), 254 (Messina-Reggio Calabria), 261 (Bronte), 262 (M. Etna). Da «Contributi preliminari alla realizzazione della carta neotettonica d'Italia », pubbl. n. 125, P.F. Geodinamica, C.N.R., pp. 247-270.

Giese P., Morelli C., 1975 - Crustal Structure in Italy. "Quaderni della Ricerca Scientifica ", n. 90. Structural Model of Italy, C.N.R.

Honnorez J., Keller J., 1968 - Xenolithe in vulkanischen Gesteinen der Aolischen Inseln (Sizilien). "Geolog. Rundschau », 57, 3, pp. 719-736.

Loddo M., Patella D., 1978 - Spectral analysis of voltage measurements for the interpretation of dipole geoelectrical soundings in low resistivity geothermal areas. "Geothermics ", 6, pp. 227-235.

Morelli C., 1970 - Physiography, gravity and magnetism of the Tyrrhenian Sea. «Boll. Geof. Teor. Appl.", 12, pp. 275-305

Morelli C., Giese P., Cassinis R., Colombi B., Guerra I., Luongo G., ScaRAScIa S., Schütte G., 1975 - Crustal structure of southern Italy. A seismic refraction profile between Puglia-Calabria-Sicily. "Boll. Geof. Teor. Appl. ", 17, pp. 183-210.

Nardi R., Puccinelli A., Patella D., 1979 - Applicazione del metodo del sondaggio dipolare profondo lungo una sezione dalle Alpi Apuane all'Appennino Pistoiese. "Atti della Società Toscana di Scienze Naturali ", serie $A, 87$. In press.

Ortolani F., 1975 - Fase tettonica mediopliocenica in Calabria: schema delle principali strutture originate. "Boll. Soc. Naturalisti in Napoli", 84.

Patella D., 1974 - On the transformation of dipole to Schlumberger sounding curves. "Geophysical Prospecting ", 22, pp. 315-329.

Patella D., 1977 - Geoelectrical survey over media with lateral discontinuities. Application to a foundation problem. "Geologia Applicata ed Idrogeologia », 12, parte I, pp. 145-161. 
Patella D., Rossi A., Tramacere A., 1979 - First results of the application of the dipole electrical sounding method in the geothermal area of Travale-Radicondoli (Tuscany). "Geothermics ", 8, pp. 111-134.

Scarascia S., Colombi B., 1971 - Interpretazione preliminare del profilo sismico e rifrazione profonda in Calabria. "Open-file report, Ist. di Geof. per la Litosfera, C.N.R., Milano ».

Selli R., 1978 - Geologia e Sismotettonica dello Stretto di Messina. Meeting on "Attraversamento dello Stretto di Messina e sua fattibilità ", Acc. Naz. Lincei, Roma, 4-6 July 1978.

Sinarp A., Davis P., Gray F., King G., 1979 - Prelininary results from a seismic array study of mount Etna. From "Report of the Royal Society sub-committee on Mount Etna (1978-79)". 